\title{
Accumulation of Antioxidants in Apricot Fruit through Ripening: Characterization of a Genotype with Enhanced Functional Properties
} \author{
Éva Stefanovits-Bányai ${ }^{2}$ \\ ${ }^{1}$ Corvinus University of Budapest, Department of Genetics and Plant Breeding, Budapest, Hungary. \\ ${ }^{2}$ Corvinus University of Budapest, Department of Applied Chemistry, Budapest, Hungary. \\ ${ }^{3}$ University of Debrecen, Institute for Extension and Development, Debrecen, Hungary. \\ ${ }^{4}$ Semmelweis University of Medicine, Department of Pharmacognosy, Budapest, Hungary.
}

Attila Hegedüs ${ }^{1,}{ }^{*}$, Péter Pfeiffer ${ }^{1}$, Nóra Papp ${ }^{2,3}$, László Abrankó ${ }^{2}$, Anna Blázovics ${ }^{4}$, Andrzej Pedryc ${ }^{1}$,

\begin{abstract}
Two apricot genotypes, 'Gönci magyarkajszi' and 'Preventa' were assayed at three ripening stages for flesh color indices $\left(L^{*}, a^{*}, b^{*}, C^{*}\right.$ and $H^{\circ}$ ), contents of total phenolics and vitamin C, and both water- and lipid-soluble antioxidant capacities (ferric reducing antioxidant power; 2,2'-diphenyl-1-picrylhydrazyl scavenging activity; total radical scavenging activity; and Photochem lipid-soluble antioxidant capacity) to compare their dynamics in the accumulation of antioxidant compounds and capacities through ripening. The increase in $a^{*}, b^{*}$ and $C^{*}$ and decrease in $H^{\circ}$ during ripening represented a color shift from green to yellow and orange due to carotenoid accumulation. Parallel to carotenoid accumulation, contents of total phenolics and vitamin $\mathrm{C}$ and antioxidant capacity increased significantly $(p \leq 0.05)$ from unripe to fully ripe fruits. More phenolics and vitamin C accumulated in fully ripe fruits of 'Preventa' than 'Gönci magyarkajszi'. The accumulation patterns of these compounds were different: while the vitamin C contents in unripe fruit of 'Preventa' and 'Gönci magyarkajszi' were identical (approx. $6 \mathrm{mg} / 100 \mathrm{~g}$ fresh weight), unripe 'Preventa' contained even more phenolics (approx. 12 mmolGA/l) than fully ripe 'Gönci magyarkajszi' ( $8 \mathrm{mmolGA} / \mathrm{l})$. Our results confirm that fully ripe 'Preventa' fruits are characterized by outstanding functional properties due to the increased accumulation of vitamin $\mathrm{C}$ and phenolics throughout the ripening process.
\end{abstract}

Key terms: antioxidant capacity, apricot, color, ripening, total polyphenolic content, vitamin C.

\section{INTRODUCTION}

Raw plant materials are considered to have valuable healthpromoting effects mainly due to the high levels of a wide range of antioxidant compounds present in their tissues (Liu, 2003, Moselhy and Ali, 2009, Papp et al., 2010, Tosun et al., 2009). The importance of antioxidant compounds is highlighted by the fact that artificial supplementation of some of these agents might even have harmful effects on the redox homeostasis of the human body (Halliwell, 2000). Recently, it has been shown that apricot (Prunus armeniaca L.) fruits provide protection against radiation and have in vivo cardio-protective activity that are associated with its antioxidant phenolic contents (Parlakpinar et al., 2009, Ugras et al., 2010). Besides polyphenolics, apricot is also a rich source of carotenoids and vitamin C (Akin et al., 2008, Hegedus et al., 2010, Ruiz et al., 2005).

Numerous factors have been shown to influence the fruit antioxidant capacity or quantity of individual antioxidant compounds in stone fruit species, including genotype (Drogoudi et al., 2008, Hegedus et al., 2010), geographic region of cultivation (Dragovic-Uzelac et al., 2007, Munzuroglu et al., 2003), harvest year (Hegedus et al., 2010) and the length of the fruit development period (Leccese et al., 2008). The biosynthesis of polyphenolic compounds has been determined to be induced by several stress effects including heat and cold, radiation etc. (Pfeiffer and Hegedus, 2011). Apricot antioxidants were also found to be sensitive to storage and processing with polyphenolics being one of the most stable groups of antioxidant compounds (Amarowicz et al., 2009, Egea et al., 2006, Jiménez et al., 2008).

The details of fruit ripening have been well studied in Prunus because of its economic and scientific relevance. The ripening of climacteric stone fruits can be marked by a steep increase in respiratory rates and ethylene evolution (Payasi and Sanwal, 2010). Biochemical changes during the ripening process of apricot were reported in contents of proteins, free amino acids, and total and soluble carbohydrates (Sharaf et al., 1989). The most characteristic feature of the ripening of apricot fruit is that its unripe green color turns yellow due to the enhanced biosynthesis of carotenoids (Katayama et al., 1971), especially b-carotene, representing 70-85\% of the total carotenoid content (Dragovic-Uzelac et al., 2007).

Considering quantitative changes in total polyphenolic contents, immature fruits showed the highest levels of polyphenols, with decreased levels at the semi-mature stage, and remaining relatively unchanged in commercially mature fruits (Dragovic-Uzelac et al., 2007). The vitamin C content in ripening fruits is said to change in a species-specific manner (Lee and Kader, 2000); however for apricot, both decreases (Egea et al., 2006) and increases (Lee and Kader, 2000) during the ripening process were reported in studies analyzing different cultivars.

Recently, the advanced selection 'Preventa' has demonstrated its outstanding antioxidant properties among 27 apricot cultivars (Hegedus et al., 2010). Our present study 
focuses on the comparison of this apricot hybrid and cultivar 'Gönci magyarkajszi' with strikingly lower antioxidant capacity and contents. Color indices were used to ensure the sampling of identical ripening stages for the two genotypes. The changes in contents of total phenolics and vitamin $C$ as well as water- and lipid-soluble antioxidant and antiradical capacities were determined at different ripening stages to compare the dynamics in the accumulation of antioxidant compounds and capacity throughout ripening and assess how the variations observed between ripe fruits of different genotypes are formed.

\section{MATERIALS AND METHODS}

Chemicals

All reagents used were of HPLC or analytical grade. Luminol, 2,2'-diphenyl-1-picrylhydrazyl and microperoxidase were obtained from Sigma; and 2,4,6-tripyridyl-s-triazine (TPTZ) and Folin-Ciocalteu's reagent from Fluka. The lipid-soluble antioxidant capacity (ACL) kits for the Photochem assay were purchased from Analytic Jena. Gallic acid monohydrate and L-ascorbic acid (Vitamin C) standards were obtained from Sigma and Fluka, respectively.

\section{Plant material}

Two apricot cultivars were used in the experiments, a commercial cultivar 'Gönci magyarkajszi' and a hybrid 'Preventa' obtained from the apricot-breeding program conducted at the Department of Genetics and Plant Breeding, Corvinus University of Budapest (CUB). Both cultivars were grafted on Myrobalan rootstock and grown in the same orchard (Szigetcsép, Central Hungary, $47^{\circ} \mathrm{N}$ latitude, $18^{\circ} \mathrm{E}$ longitude and $95 \mathrm{~m}$ altitude). Fruit were harvested at three ripening stages based on fruit size and background fruit color (unripe: undeveloped green fruits, half-ripe: normal sized and slightly yellowing fruits, fully ripe: normal sized, yellow colored with red blush). Fruit were picked and frozen at $-80{ }^{\circ} \mathrm{C}$ until analysis. For analysis, fruits were partially thawed, stones were removed, apricots (with skin) were cut into small pieces, and processing of purees was performed using a $350 \mathrm{~W}$ house blender (Bosch MMR0800, Stuttgart, Germany). This procedure is expected to extract a fraction of the skin antioxidants. Homogenization was carried out at $4{ }^{\circ} \mathrm{C}$ for $5 \mathrm{~min}$. The puree was immediately used for analysis.

Fruit color indices

The CIELAB color indices of apricot were determined with a MOMCOLOR 100 instrument (MOM, Budapest, Hungary) on the skin surface (ground color) and flesh (cut surface) of 15 fruits for each genotype. The color space coordinates $L^{*}$, $a^{*}, b^{*}$ were determined, after which hue angle $\left(H^{\circ}=\right.$ arctangent $\left.\left(b^{*} / a^{*}\right)\right)$, and chroma $\left[C^{*}=\left(a^{* 2}+b^{* 2}\right)^{1 / 2}\right]$ were calculated.

Extraction for redox assays

Apricots were divided into three batches for independent extractions of approximately $100 \mathrm{~g}$ fresh weight. Fruits were halved, then homogenized and centrifuged $\left(4{ }^{\circ} \mathrm{C}, 35 \mathrm{~min}\right.$, $18750 \mathrm{~g}$ ), and supernatants were used for the redox assays.
Antioxidant activity according to the ferric reducing antioxidant power (FRAP) assay

Antioxidant capacity was determined using the FRAP assay (Benzie and Strain, 1996). Absorbance was measured at $593 \mathrm{~nm}$ at 0 and $6 \mathrm{~min}$. Ascorbic acid was used as a control to obtain the standard curve and FRAP value was calculated relevant to the activity of ascorbic acid and expressed as ascorbic acid (AA) equivalents.

DPPH radical scavenging activity

The 2,2'-diphenyl-1-picrylhydrazyl (DPPH) radical-scavenging activity was measured spectrophotometrically (Blois, 1958, Hatano et al., 1988). Absorbance of the methanolic DPPH-dye was monitored at $517 \mathrm{~nm}$. For characterization of the activity, DPPH degradation was measured using 10-fold diluted supernatants.

Total radical scavenger activity (TRSA)

Total radical scavenger activity (TRSA) was measured using a chemiluminescense assay (Blazovics et al., 1999). A Lumat 9501 luminometer (Berthold, Bad Wildbad, Germany) was used for total scavenger capacity determination of the apricot extracts. The emitted light was measured in the 390-620 nm range. Reaction mixture contained $\mathrm{H}_{2} \mathrm{O}_{2}\left(0.30 \mathrm{ml}, 10^{-4}\right.$ dilution of $\left.33 \% \mathrm{H}_{2} \mathrm{O}_{2}\right)$, microperoxidase $(0.30 \mathrm{ml}$ of $1 \mathrm{mM})$ as a catalyst and alkaline luminol solution ( $\mathrm{pH} 9.8)(0.050 \mathrm{ml}$ of $0.07 \mathrm{mM})$. The emitted photons were accumulated during a $30 \mathrm{~s}$ exposure and expressed in relative light units (RLU\%). Extraction supernatants $(0.050 \mathrm{ml}$ of 100 -fold dilution) were added to the luminol solution and vortexed (10 s) before analysis.

\section{Photochem assay}

The superoxide radical/luminol scavenging capacity was measured in a photochemiluminescence assay with a Photochem ${ }^{\circledR}$ instrument (Analytik Jena AG, Jena, Germany). Superoxide anion radicals are generated from luminol, a photosensitizer, when exposed to UV light. The lipophilic radical scavenging activities were measured according to Popov and Lewin (1996) using the ACL kit provided by the manufacturer. The extraction was also carried out according to the manufacturer's protocol using methanol. Results are expressed as nmol Trolox eq./ 1 fruit juice.

Measurement of total phenolic content (TPC)

Total phenolic content (TPC) was measured using FolinCiocalteu's reagent according to the method of Singleton and Rossi (1965). Absorbance was monitored at $760 \mathrm{~nm}$ and the content of soluble phenols was calculated from a standard curve based on gallic acid concentrations.

\section{Determination of vitamin $C$ content}

Vitamin $\mathrm{C}$ content was determined using high performance liquid chromatography (HPLC) (Agilent Technologies, Waldbronn, Germany) coupled with a diode array detector. The extraction and measurement were carried out according to the previously described method (Engel et al., 2010). Based 
on the UV spectra of ascorbic acid $254 \mathrm{~nm}$ was chosen for the detection.

\section{Statistical analyses}

Data presented for each cultivar and ripening stage represent the mean values determined from three independent homogenates. After testing for normal distribution and equality of variances, one-way analysis of variance (ANOVA) was carried out and significant differences among the six data (three maturity stages by two genotypes) within a background or flesh color grouping were calculated according to a Duncan's multiple range test with $p \leq 0.05$ being considered significant in all analyses.

\section{RESULTS AND DISCUSSION}

\section{Changes in color, total phenolic and vitamin $C$ contents}

The most striking feature of apricot ripening is the change in color from green to yellow due to carotenoid accumulation in fruit peel and flesh (Katayama et al., 1971). Similar to other reports (Akin et al., 2008, Ruiz et al., 2005), the $L^{*}, a^{*}, b^{*}$ and $C^{*}$ values in the skin were, in general, higher than in the flesh for each genotype, while $H^{\circ}$ did not show consistent differences between skin and flesh. The lightness factor $L^{*}$, measured on the fruit skin, increased during the entire ripening process for both cultivars. A great proportion of this increase coincided with the first phase of the ripening process characterized by chlorophyll degradation in developing fruits. The increase in flesh $L^{*}$ was also evident in the half-ripe fruits followed by a slight, non-significant decrease in ripe fruits. This indicates that fruit become lighter during an early stage of ripening due to chlorophyll loss, and subsequently darken slightly as carotenoid accumulates in the fruits. This is further confirmed by the changes in other color indices: the increases in $a^{*}, b^{*}$ and $C^{*}$ and decrease in $H^{\circ}$ represents a color shift from green to yellow and orange. Hue angle in itself was shown to be closely correlated $(r=0.94)$ to total carotenoid content of apricot flesh (Ruiz et al., 2005) and hence this parameter was a suitable choice to monitor changes in carotenoid contents during ripening. $H^{\circ}$ values are expressed in degrees and decreased from $120^{\circ}$ to $70^{\circ}$ during the ripening period, with fruits first appearing green in color and gradually changing to yellow or orange. A much greater increase in $H^{\circ}$ values was detected between half-ripe and fully ripe stages as these ripening stages were determined on the basis of skin color. A notable difference was detected in the dynamics of change in flesh $H^{\circ}$ values of 'Gönci magyarkajszi' and 'Preventa', indicating that a rapid increase in the carotenoid content coincides with the later stages of ripening of 'Gönci magyarkajszi' fruits, while 'Preventa' is characterized by a more consistent carotenoid increase in flesh from unripe to fully ripe stages. However, both genotypes showed very similar $H^{\circ}$ values in skin. Ruiz et al. (2005) analyzed several apricot breeding lines with flesh colors ranging from white to orange. A difference in the $H^{\circ}$ values of 93.45 to 67.75 represented a variation in total flesh carotenoids content of 1.51 and $16.5 \mathrm{mg} / 100 \mathrm{~g}$ fresh weight, respectively. The $H^{\circ}$ values determined in the present study decreased from the initial level of 116-117 to the value of 7073 in fully ripe fruit. The close correlation between hue angle and total carotenoid content of apricot flesh indicates that carotenoids accumulated from practically zero to approx. 16 $\mathrm{mg} / 100 \mathrm{~g}$ during the examined period of the apricot ripening, based on regressions developed by Ruiz et al. (2005).

The total phenolic content of apricot increased steadily throughout the ripening period (Fig. 1A). The most notable difference between apricot accessions was the TPC of unripe 'Preventa' fruit being significantly higher than that of the ripe 'Gönci magyarkajszi'. In addition, more phenolics accumulated in 'Preventa' (9 mmolGA/l) than 'Gönci magyarkajszi' (4 mmolGA/l) during ripening. Another interesting feature was the proportion of TPC increase between the ripening stages: 'Gönci magyarkajszi' and 'Preventa' fruits accumulated 70\% of TPC in the first and second half of the ripening process, respectively. It reveals that TPC formation became more intensive at an earlier ripening stage in 'Preventa' fruits as compared to 'Gönci magyarkajszi' and remained active toward the end of the ripening period. In contrast to our data, unripe fruits were previously shown to contain the highest level of polyphenols, which decreased at the half-ripe stage and did not change appreciably in fully ripe fruits (DragovicUzelac et al., 2007). The inconsistencies might be explained by genotypic differences or differences between the assays used. As a possibility, while the Folin assay clearly detects the total Folin reducing ability contributed by all polyphenolics present in the sample, it might also be influenced by nonphenolic antioxidants (Huang et al., 2005). In contrast, only a selected number of phenolic compounds were quantified using HPLC analysis. The extent of hydroxylation, unsaturation in the $\mathrm{C}$ ring as well as o-dihydroxyl structure in the $\mathrm{B}$ ring all contribute to the antioxidant potential of flavonoids (RiceEvans et al., 1996). In addition, a marked decrease in the total phenolic content might induce only a slight decrease in total antioxidant capacity if those polyphenolics having higher antioxidant capacity (Pulido et al., 2000, Rice-Evans et al., 1996) are retained more than those with lower antioxidant power. However, clarification will require phytochemical and gene expression analysis. Another possibility might be that the ripening stages in the two studies were not exactly identical and hence covered different physiological conditions.

The vitamin $C$ content of apricot gradually increased through the ripening stages (Fig. 1B). Although ripe 'Preventa' fruit contained approx. $25 \%$ more vitamin $\mathrm{C}$ than 'Gönci magyarkajszi', vitamin C contents in unripe fruits of both cultivars were identical. During ripening, 'Preventa' accumulated more vitamin C than 'Gönci magyarkajszi', and the proportions of the accumulated quantities were very similar in both cultivars: $40 \%$ of the total increase occurred in the first half of the ripening process, and the remaining $60 \%$ in the latter half. This is very similar to the changes that occurred during the ripening of 'Tilton' apricots (Lee and Kader, 2000), suggesting that the dynamics in the accumulation of vitamin $C$ in apricot fruit are less influenced by genotype or environmental effects and more by the physiological consequences of ripening. Plants convert uronic acids to ascorbic acid as a mechanism to salvage carbon arising from the breakdown of cell walls, as occurs during fruit ripening and softening (Davey et al., 2000).

\section{Changes in antioxidant and antiradical capacities}

There are only a limited number of studies describing the changes in total antioxidant capacity of Prunus fruit 
throughout ripening (Díaz-Mula et al., 2008, Kristl et al., 2011, Serrano et al., 2005). Ferric reducing antioxidant power was a suitable parameter to characterize the antioxidant capacity of various fruit crops including apricots (Guo et al., 2003, Hegedus et al., 2008, Hegedus et al., 2010, Papp et al., 2010). 'Preventa' was characterized by much higher antioxidant capacity in all assays (Fig. 1). Perhaps the specific genetic constitutions of 'Gönci magyarkajszi' and 'Preventa' might account for the huge variations in antioxidant capacity between these two genotypes, since their origins reside in the European and Central Asian ecogeographic groups, respectively (Halász, 2007). Differences among all three ripening stages were also evident and seemed to be very similar from the tendency detected by the TPC assay (Fig. $1 \mathrm{~A}, \mathrm{C})$. Correlation between FRAP and TPC data was close in many cases (Hegedus et al., 2010, Tosun et al., 2009), which might be explained since a considerable fraction of antioxidant power is attributed to polyphenolics (Jacobo-Velázquez and Cisneros-Zevallos, 2009) and also the similar chemistry of these assays (Huang et al., 2005).

The DPPH radical scavenging method differentiated between the assayed cultivars by demonstrating consistently higher antiradical activities for 'Preventa' than 'Gönci magyarkajszi' across all ripening stages (Fig. 1D). While unripe and half-ripe fruits of either cultivar did not exhibit differences in antiradical activities, fully ripe fruit were
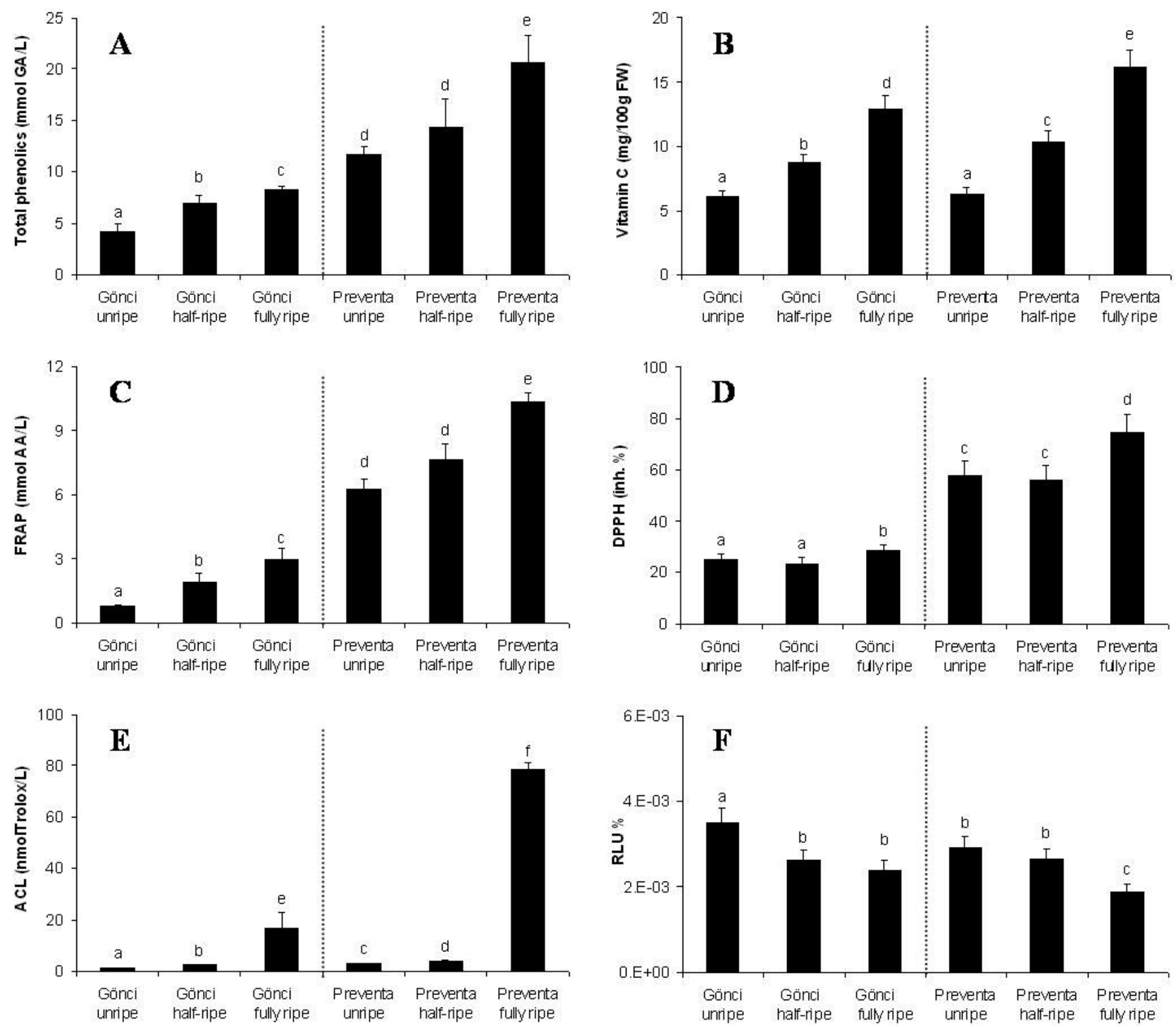

Figure 1: Total phenolic content (A), vitamin C content (B), ferric reducing antioxidant power, FRAP (C), 2,2'-diphenyl-1-picrylhydrazyl, DPPH, scavenging activity (D), Photochem lipid-soluble antioxidant capacity, ACL (E), and total radical scavenging activity, TRSA (F) of 'Gönci magyarkajszi' and 'Preventa' apricots at different ripening stages. Vertical lines represent SDs ( $n=3)$ and different letters indicate significantly different values at $\mathrm{p} \leq 0.05$ according to a Duncan's multiple range test. 
characterized by significantly higher DPPH scavenging activity. Since DPPH is a stable free radical that is very different from the physiologically relevant transient peroxyl radicals (Huang et al., 2005) other antiradical assays were also carried out. The Photochem ACL parameter was established to characterize lipid-soluble antiradical capacity against superoxide/luminol radicals (Popov and Lewin, 1996), although it was confirmed to also be influenced by watersoluble antioxidants (e.g. ascorbic acid) while some lipidsoluble compounds (e.g. carotenoids) seemed to not contribute to the ACL values (DiNardo et al., 2004, Hegedus et al., 2010). Significant but smaller scale differences occurred between unripe and half-ripe fruits of both cultivars than between unripe/half-ripe and fully ripe fruits (Fig. 1E). The tendency is similar to that obtained by the DPPH assay, although the proportions were different. It suggests that $\mathrm{DPPH}$ and ACL measure a similar group of antioxidants but ACL is a more sensitive method.

A chemiluminescent assay, TRSA, characterizes the hydroxyl and luminol radical scavenging capacity of samples. The lower the detected luminometric light intensity, the higher the total scavenging ability of antioxidants is in the sample. An increase in the TRSA was detected between the unripe and half-ripe stages of 'Gönci magyarkajszi' fruits, which did not change remarkably in fully ripe fruit (Fig. 1F). In contrast, TRSA of 'Preventa' did not change during the first half of the ripening process but became significantly higher in ripe fruit. This tendency is very similar to the proportions of TPC accumulation throughout ripening, suggesting that TRSA is more sensitive for these compounds. However, other compounds, including carotenoids, may also influence the TRSA values (Hegedus et al., 2010), while carotenoids lack ferric reducing ability (Pulido et al., 2000). The variations in results of antioxidant assays are possibly due to the diverse reactions taking place among different oxidizing agents (ferrous ions, DPPH, hydroxyl, superoxide and luminol radicals) and different classes of antioxidants in the sample.

In conclusion, the flesh $H^{\circ}$ values indicated a rapid increase in the carotenoid content during the later stages of ripening of 'Gönci magyarkajszi' fruits, while 'Preventa' was characterized by a more consistent carotenoid increase throughout ripening. The fully ripe fruits of 'Preventa' contained more polyphenolics and vitamin $C$ than 'Gönci magyarkajszi' and hence might be considered as a natural source of healthpromoting agents. However, the accumulation patterns of the antioxidants were very different in the two assayed apricots: the vitamin $C$ content of the unripe fruit of 'Preventa' and 'Gönci magyarkajszi' were identical, while unripe 'Preventa' contained even more polyphenolics than fully ripe 'Gönci magyarkajszi'. The changes in the antioxidant capacity during ripening were dependent on the choice of assay; however, all methods demonstrated that contents of individual antioxidant molecules and antioxidant capacity increased in both tested cultivars throughout ripening. Our results clearly confirmed that fruits should be harvested at fully ripe stage to provide considerable health-benefits (Díaz-Mula et al., 2008).

In addition, our data may also bear ecological relevancies. It has been long known that fruits accumulate sugars, acids and minerals during ripening to supply energy and nutrients for seed dispersing animals. It is alluring to consider that

TABLE 1

'Preventa' and 'Gönci magyarkajszi' mean values ( $\pm \mathrm{SD}$ ) of color indices $L^{*}, a^{*}, b^{*}, C^{*}$ and $H^{\circ}$ of fruit surface (background color) and flesh across ripening stages*

\begin{tabular}{|c|c|c|c|c|c|}
\hline Genotype / ripening stage & $L^{*}$ & $a^{*}$ & $b^{*}$ & $C^{*}$ & $H^{\mathrm{o}}$ \\
\hline \multicolumn{6}{|l|}{ Background color } \\
\hline Gönci magyarkajszi / unripe & $53.34 \pm 1.10 \mathrm{a}$ & $-20.05 \pm 2.55 a$ & $36.14 \pm 2.05 a$ & $41.33 \pm 0.84 \mathrm{~b}$ & $119.02 \pm 3.83 a$ \\
\hline Gönci magyarkajszi / half-ripe & $60.99 \pm 1.75 b$ & $-15.58 \pm 1.26 b$ & $37.85 \pm 1.90 \mathrm{a}$ & $40.93 \pm 1.00 \mathrm{~b}$ & $112.37 \pm 2.81 b$ \\
\hline Gönci magyarkajszi / fully ripe & $62.95 \pm 2.31 b$ & $10.79 \pm 2.88 \mathrm{c}$ & $42.94 \pm 3.13 b$ & $44.27 \pm 1.16 b$ & $75.89 \pm 3.21 \mathrm{c}$ \\
\hline Preventa / unripe & $52.71 \pm 2.08 \mathrm{a}$ & $-16.17 \pm 2.40 \mathrm{a}$ & $32.80 \pm 1.68 \mathrm{a}$ & $36.57 \pm 1.52 \mathrm{a}$ & $116.24 \pm 6.49 a$ \\
\hline Preventa / half-ripe & $62.40 \pm 1.83 b$ & $-12.52 \pm 1.92 b$ & $41.60 \pm 1.35 b$ & $43.45 \pm 1.35 b$ & $106.74 \pm 6.00 \mathrm{ab}$ \\
\hline Preventa / fully ripe & $63.20 \pm 2.45 b$ & $7.43 \pm 1.70 \mathrm{c}$ & $47.23 \pm 2.33 c$ & $47.81 \pm 1.32 \mathrm{c}$ & $81.06 \pm 5.49 \mathrm{c}$ \\
\hline \multicolumn{6}{|l|}{ Flesh color } \\
\hline Gönci magyarkajszi / unripe & $41.07 \pm 3.72 \mathrm{a}$ & $-12.23 \pm 4.35 a$ & $24.57 \pm 3.38 \mathrm{a}$ & $27.45 \pm 1.50 \mathrm{a}$ & $116.46 \pm 1.51 \mathrm{a}$ \\
\hline Gönci magyarkajszi / half-ripe & $59.28 \pm 1.23 c$ & $-15.96 \pm 2.05 a$ & $36.41 \pm 1.51 b$ & $39.76 \pm 1.13 b$ & $113.67 \pm 2.18 \mathrm{a}$ \\
\hline Gönci magyarkajszi / fully ripe & $58.47 \pm 1.11 b c$ & $17.13 \pm 2.10 \mathrm{c}$ & $49.04 \pm 1.92 \mathrm{c}$ & $51.94 \pm 2.06 \mathrm{~d}$ & $70.75 \pm 1.15 c$ \\
\hline Preventa / unripe & $56.33 \pm 1.22 \mathrm{~b}$ & $-16.74 \pm 2.45 a$ & $32.67 \pm 3.54 \mathrm{ab}$ & $36.71 \pm 1.34 b$ & $117.13 \pm 1.37 \mathrm{a}$ \\
\hline Preventa / half-ripe & $60.20 \pm 2.12 c$ & $-5.80 \pm 1.55 b$ & $42.92 \pm 1.66 b$ & $43.31 \pm 2.06 c$ & $97.70 \pm 1.06 \mathrm{~b}$ \\
\hline Preventa / fully ripe & $59.77 \pm 1.79 c$ & $14.20 \pm 2.22 \mathrm{c}$ & $47.27 \pm 1.92 \mathrm{c}$ & $49.36 \pm 1.44 \mathrm{~cd}$ & $73.28 \pm 1.35 c$ \\
\hline
\end{tabular}

${ }^{*}$ Means followed by the same letter within a background or flesh color grouping do not differ significantly at the $p \leq 0.05$ level according to a Duncan multiple range test. 
fruit consumption also provides a kind of antioxidant reward (Schaefer et al., 2008) for frugivores since the increase in water-soluble and colorless antioxidants throughout ripening seems to be closely coupled with carotenoid accumulation as a potential visual signal for them.

\section{ACKNOWLEDGEMENT}

This study was financed by the NKTH-OTKA K68921 OTKA K84290 and TÁMOP 4.2.1./B-09/01-KMR-2010-0005 (3.1.3) grants. Attila Hegedús is grateful for receiving a János Bolyai Scholarship, HAS. The authors express their thanks to Dr. Craig A. Ledbetter for his valuable comments and critically revising the English of the manuscript.

\section{REFERENCES}

AKIN EB, KARABULUT I, TOPCU A (2008) Some compositional properties of main Malatya apricot (Prunus armeniaca L.) varieties. Food Chem 107:939-948.

AMAROWICZ R, CARLE R, DONGOWSKI G, DURAZZO A, GALENSA R, KAMMERER D, MAIANI G, PISKULA MK (2009) Influence of postharvest processing and storage on the content of phenolic acids and flavonoids in foods. Mol Nutr Food Res 53:S151-S183.

BENZIE IFF, STRAIN JJ (1996) The ferric reducing ability of plasma (FRAP) as a measure of "antioxidant power": The FRAP assay. Anal Biochem 239:70-76.

BLAZOVICS A, KOVACS A, LUGASI A, HAGYMASI K, BIRO L, FEHER J (1999) Antioxidant defense in erythrocytes and plasma of patients with active and quiescent Crohn disease and ulcerative colitis: A chemiluminescent study. Clin Chem 45:895-896.

BLOIS MS (1958) Antioxidant determination by the use of a stable free radical. Nature 4617:1198-1200.

DAVEY MW, MONTAGU MV, INZÉ D, SANMARTÍN M, KANELLIS A SMIRNOFF N, BENZIE IJ, STRAIN JJ, FAVELL D, FLETCHER J (2000) Plant L-ascorbic acid: chemistry, function, metabolism, bioavailability and effects of processing. J Sci Food Agr 80:825-860.

DÍAZ-MULA HM, ZAPATA PJ, GUILLÉN F, CASTILLO S, MARTÍNEZROMERO D, VALERO D, SERRANO M (2008) Changes in physicochemical and nutritive parameters and bioactive compounds during development and on-tree ripening of eight plum cultivars: a comparative study. J Sci Food Agr 88:2499-2507.

DINARDO JC, LEWIS JA, NEUDECKER BA, MAIBACH HI (2004) Antioxidants compared in a new protocol to measure protective capacity against oxidative stress-part II. J Am Acad Dermatol 50:P30-P30.

DRAGOVIC-UZELAC V, LEVAJ B, MRKIC V, BURSAC D, BORAS M (2007) The content of polyphenols and carotenoids in three apricot cultivars depending on stage of maturity and geographical region. Food Chem 102:966-975.

DROGOUDI PD, VEMMOS S, PANTELIDIS G, PETRI E, TZOUTZOUKOU C, KARAYIANNIS I (2008) Physical characters and antioxidant, sugar, and mineral nutrient contents in fruit from 29 apricot (Prunus armeniaca L.) cultivars and hybrids. J Agr Food Chem 56:10754-10760.

EGEA MI, MURCIA MA, SÁNCHEZ-BEL P, ROMOJARO F, MARTÍNEZMADRID MC (2006) Influence of different storage treatments on antioxidant system of apricot var. 'Búlida'. Acta Hort 717:337-342.

ENGEL R, ABRANKÓ L, STEFANOVITS-BÁNYAI É, FODOR P (2010) Simultaneous determination of water soluble vitamins in fortified food products. Acta Aliment Hung 39:48-58.

GUO C, YANG J, WEI J, LI Y, XU J, JIANG Y (2003) Antioxidant activities of peel, pulp and seed fractions of common fruits as determined by FRAP assay. Nutr Res 23:1719-1726.

HALÁSZ J (2007) Review of self-(in)compatibility in apricot (Prunus armeniaca L.). World J Agr Sci 3:670-677.

HALLIWELL B (2000) The antioxidant paradox. Lancet 355:1179-1180.

HATANO T, KAGAWA H, YASUHARA T, OKUDA T (1988) Two new flavonoids and other constituents in licorice root: their relative astringency and radical scavenging effects. Chem Pharm Bull 36:2090-2097.

HEGEDUS A, BALOGH E, ENGEL R, SIPOS BZ, PAPP J, BLAZOVICS A, STEFANOVITS-BANYAI E (2008) Comparative nutrient element and antioxidant characterization of berry fruit species and cultivars grown in Hungary. HortSci. 43:1711-1715.
HEGEDUS A, ENGEL R, ABRANKÓ L, BALOGH E, BLÁZOVICS A HERMÁN R, HALÁSZ J, ERCISLI S, PEDRYC A, STEFANOVITSBÁNYAI É (2010) Antioxidant and antiradical capacities in apricot (Prunus armeniaca L.) fruits: Variations from genotypes, years, and analytical methods. J. Fd Sci. 75:C722-C730.

HUANG DJ, OU BX, PRIOR RL (2005) The chemistry behind antioxidant capacity assays. J Agric Food Chem 53:1841-1856.

JACOBO-VELÁZQUEZ DA, CISNEROS-ZEVALLOS L (2009) Correlations of antioxidant activity against phenolic content revisited: A new approach in data analysis for food and medicinal plants. J Food Sci 74:R107-R113.

JIMÉNEZ A, MARTÍNEZ-TOMÉ M, EGEA I, ROMOJARO F, MURCIA M (2008) Effect of industrial processing and storage on antioxidant activity of apricot (Prunus armeniaca v. bulida). Eur Food Res Technol 227:125-134.

KATAYAMA T, NAKAYAMA TOM, LEE TH, CHICHESTER CO (1971) Carotenoid transformations in ripening apricots and peaches. J Food Sci 36:804-806

KRISTL J, SLEKOVEC M, TOJNKO S, UNUK T (2011) Extractable antioxidants and non-extractable phenolics in the total antioxidant activity of selected plum cultivars (Prunus domestica L.): Evolution during on-tree ripening. Food Chem 125:29-34.

LECCESE A, BARTOLINI S, VITI R (2008) Total antioxidant capacity and phenolics content in fresh apricots. Acta Aliment Hung 37:65-76.

LEE SK, KADER AA (2000) Preharvest and postharvest factors influencing vitamin C content of horticultural crops. Postharvest Biol Tec 20:207-220.

LIU RH (2003) Health benefits of fruit and vegetables are from additive and synergistic combinations of phytochemicals. Am. J. clin. Nutr. 78:517S-520S.

MOSELHY SS, ALI HKH (2009) Hepatoprotective effect of cinnamon extracts against carbon tetrachloride induced oxidative stress and liver injury in rats. Biol Res 42:93-98.

MUNZUROGLU O, KARATAS F, GECKIL H (2003) The vitamin and selenium contents of apricot fruit of different varieties cultivated in different geographical regions. Food Chem 83:205-212.

PAPP N, SZILVÁSSY B, ABRANKÓ L, SZABÓ T, PFEIFFER P, SZABÓ Z, NYÉKI J, ERCISLI S, STEFANOVITS-BÁNYAI É, HEGEDUS A (2010) Main quality attributes and antioxidants in Hungarian sour cherries: identification of genotypes with enhanced functional properties. Int. J. Fd Sci. Technol. 45:395-402.

PARLAKPINAR H, OLMEZ E, ACET A, OZTURK F, TASDEMIR S, ATES B, GUL M, OTLU A (2009) Beneficial effects of apricot-feeding on myocardial ischemia-reperfusion injury in rats. Food Chem Toxicol 47:802-808.

PAYASI A, SANWAL G (2010) Ripening of climacteric fruits and their control. J Food Biochem 34:679-710.

PFEIFFER P, HEGEDUS A (2011) Review of the molecular genetics of flavonoid biosynthesis in fruits. Acta Aliment Hung 40:150-163.

POPOV IN, LEWIN G (1996) Photochemiluminescent detection of antiradical activity; IV: testing of lipid-soluble antioxidants. J Biochem Bioph Meth 31:1-8.

PULIDO R, BRAVO L, SAURA-CALIXTO F (2000) Antioxidant activity of dietary polyphenols as determined by a modified ferric reducing/ antioxidant power assay. J Agr Food Chem 48:3396-3402.

RICE-EVANS CA, MILLER NJ, PAGANGA G (1996) Structure-antioxidant activity relationships of flavonoids and phenolic acids. Free Radical Bio Med 20:933-956

RUIZ D, EGEA J, TOMAS-BARBERAN FA, GIL MI (2005) Carotenoids from new apricot (Prunus armeniaca L.) varieties and their relationship with flesh and skin color. J Agr Food Chem 53:6368-6374.

SCHAEFER HM, MCGRAW K, CATONI C (2008) Birds use fruit colour as honest signal of dietary antioxidant rewards. Funct Ecol 22:303-310.

SERRANO M, GUILLEN F, MARTÍNEZ-ROMERO D, CASTILLO S, VALERO D (2005) Chemical constituents and antioxidant activity of sweet cherry at different ripening stages. J Agr Food Chem 53:2741-2745.

SHARAF A, AHMED FA, EL-SAADANY SS (1989) Biochemical changes in some fruits at different ripening stages. Food Chem 31:19-28.

SINGLETON VL, ROSSI JA, JR. (1965) Colorimetry of total phenolics with phosphomolybdic-phosphotungstic acid reagents. Am J Enol Viticult 16:144-158.

TOSUN M, ERCISLI S, SENGUL M, OZER H, POLAT T, OZTURK E (2009) Antioxidant properties and total phenolic content of eight Salvia species from Turkey. Biol Res 42:175-181.

UGRAS M, Y., KURUS M, ATES B, SOYLEMEZ H, OTLU A, YILMAZ I (2010) Prunus armeniaca L. (apricot) protects rat testes from detrimental effects of low-dose x-rays. Nutr Res 30:200-208. 